\title{
СУЧАСНІ МОЖЛИВОСТІ УДОСКОНАЛЕННЯ АЛГОРИТМУ ДІАГНОСТИКИ ТА ПРОГНОЗУВАННЯ НАСЛІДКУ ІНФАРКТУ ГОЛОВНОГО МОЗКУ
}

\section{Медичний інститут Сумського державного університету}

РЕЗЮМЕ. В статті представлені результати дослідження функціонального стану показників симпатоадреналової системи хворих на інфаркт головного мозку (ІГМ). Розроблено нові діагностично-прогностичні критерії захворювання на основі виявлених змін.

Мета - удосконалення діагностичного алгоритму дослідження хворих у гострому періоді ІГМ з урахуванням особливостей змін $\beta$-адренергічної активності цитоплазматичних мембран (APM) еритроцитів та встановлення нових прогностичних чинників виходу захворювання.

Матеріал і методи. Основою роботи були матеріали комплексного обстеження 350 хворих із першим у житті ІГМ на 1-у, 10-у та 21-у доби захворювання. Тяжкість стану і ступінь неврологічного дефіциту об'єктивізували за допомогою шкали інсульту Національного інституту здоров'я США (NIHSS) з оцінкою в балах у перші години захворювання, в динаміці лікування на 10-ту та 21-шу доби. Було виділено 2 клінічні групи: 1-а (n=183) - хворі в стані

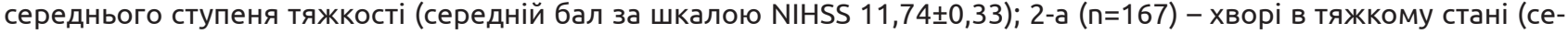

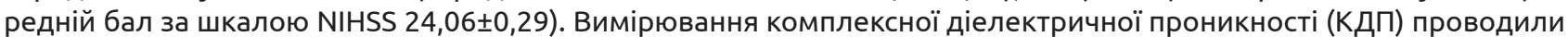
методом КВЧ діелектрометрії. Зміни осмотичної резистентності еритроцитів (ОРЕ) під дією $\beta$-адреноблокатора (ß-АБ) визначали методом фотоелектронної колориметрії.

Результати. У дебюті ІГМ відбувається достовірне підвищення значень ß-АРМ в 2,4 раза порівняно з контро-

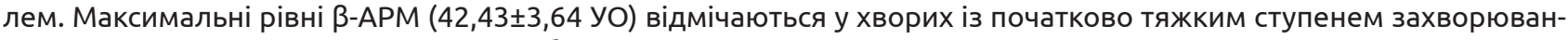
ня, що вказує на значне напруження роботи симпатоадреналової системи у даних хворих.

У ході проведеного дослідження було вперше розроблено інформативний комплексний підхід для оцінки ß-АРМ еритроцитів периферійної крові у хворих на ІГМ, який заснований на аналізі змін їх діелектричних характеристик і ступеня ОРЕ під дією адренергічних лікарських засобів.

Висновки. Застосування даного підходу показало, що відхилення КДП еритроцитів, що були індуковані адренергічними речовинами, є проявом специфічної реакції клітин і залежать від функціонального стану симпатоадреналової системи.

КлючОВІ СлОВА: симпатоадреналова система; рецептор; діагностика; мембрана; реактивність.

Вступ. Особливе місце серед найгостріших медико-соціальних проблем, що завдають суспільству величезних економічних збитків, посідає мозковий інсульт, у зв'язку з високими рівнями захворюваності, летальності, інвалідизації та соціальною дезадаптацією хворих [1-3]. За даними Всесвітньої організації охорони здоров'я, в світі зареєстровано близько 16,9 млн хворих, що перенесли гостре порушення мозкового кровообігу (ГПМК) [4]. Приблизно третина з них помирає за рік [5]. Інфаркт головного мозку (ІГМ) посідає перше місце у структурі даних порушень. Його частка становить близько 80 \% усіх інсультів [6].

На жаль, статистика інсультів в Україні має тенденцію до подальшого погіршення, тоді як у деяких країнах ситуація суттєво покращується $[7,8]$. Це пов'язано з украй повільним впровадженням сучасних стратегій лікування, лише адже лише 1315 \% хворих госпіталізують у межах терапевтичного вікна, а частина з них узагалі лікуються амбулаторно і не отримують адекватної допомоги $[9,10]$.

3 огляду на наведені факти стає очевидною значущість і актуальність вказаної проблеми. У зв'язку з цим величезного значення набуває вивчення провідних патогенетичних механізмів ІГМ для розуміння шляхів удосконалення як діагностики, так і методів лікування.

Останніми роками була сформульована патогенетична концепція гострої церебральної ішемії у вигляді швидких специфічних структурно-функціональних змін мозкової тканини. На сьогодні вкрай важливим і потужним чинником, який прямо впливає на тяжкість захворювання та визначає його наслідок [11], $\epsilon$ функціональний стан мембрано-рецепторного комплексу (МРК) клітин не тільки в зоні ураження, а й у всьому організмі $[12,13]$.

Каскад патологічних біохімічних реакцій у вогнищі гіпоксії в першу чергу призводить до ураження зовнішніх цитоплазматичних мембран клітин і їх рецепторного апарату $[14,15]$. У патогенезі ІГМ істотне місце належить гіперреактивності центрів симпатичної нервової системи з наступною стимуляцією підлеглих нейрогуморальних факторів, а тісно пов'язана з нею симпатоадреналова система бере безпосередню участь не тільки у забезпеченні адекватної мікроциркуляції, а й у модулюванні росту та диференціюванні тканин, фізіологічних коливаннях гемодинамічних і нейроендокринних констант, що прямо впливає на наслідок захворювання [16-18]. 
Огляди літератури, оригінальні дослідження, погляд на проблему, випадок з практики, короткі повідомлення

Структурно-функціональні зміни мозкової тканини за умов гострої церебральної ішемії значною мірою корелюють із порушеннями їх електрофізичних характеристик, таких як зрушення гідратного оточення біологічних молекул пошкоджених тканин, що радикально можуть змінювати метаболізм клітин $[19,20]$. Зазначені розлади дуже добре ідентифікуються за допомогою мікрохвильових методів, одним з яких $є$ КВЧ діелектрометрія.

Одним із найважливіших критеріїв оцінки функціонального стану всього організму $\epsilon$ адренергічна активність цитоплазматичних мембран (APM), що забезпечується коректною роботою МРК і відіграє провідну роль у патогенезі ІГМ [21, 22].

В даному аспекті зазначені механізми патогенезу ІГМ все ще залишаються маловивченими або практично не вивченими. Досі немає єдиного підходу до методики визначення активності симпатоадреналової системи, отже, немає й однозначної відповіді щодо правильного вибору засобів її діагностики.

Мета - удосконалити діагностичний алгоритм дослідження хворих у гострому періоді ІГМ 3 урахуванням особливостей змін $\beta$-адренорецепції та встановити нові прогностичні чинники наслідку захворювання.

Матеріал і методи дослідження. Основою роботи були матеріали комплексного обстеження 350 хворих із першим у житті ІГМ на 1-у, 10-у та 21-у доби захворювання. Тяжкість стану і ступінь неврологічного дефіциту об'єктивізували за допомогою шкали інсульту Національного інституту здоров'я CША (NIHSS) з оцінкою в балах у перші години захворювання, в динаміці лікування на 10-ту та 21-шу доби. На підставі цього всі хворі були поділені на
2 клінічні групи: 1-а (n=183) - хворі в стані середнього ступеня тяжкості (середній бал за шкалою NIHSS $11,74 \pm 0,33) ; 2$-а ( $n=167)$ - хворі в тяжкому стані (середній бал за шкалою NIHSS 24,06士0,29).

Вимірювання комплексної діелектричної проникності (КДП, $\left.\Delta \varepsilon^{\prime}\right)$ проводили методом КВЧ діелектрометрії. Зміни осмотичної резистентності еритроцитів (ОРЕ) під дією $\beta$-адреноблокатора

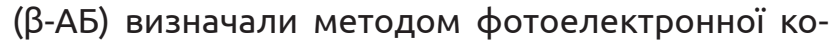
лориметрії. Статистичний аналіз результатів досліджень проводили з використанням програми Statistica 6.0 (StatSoft Inc., США) відповідно до загальноприйнятих методик.

Дослідження функціонального стану адренергічної рецепторної системи у хворих у гострому періоді ІГМ з використанням методу визначення ОРЕ під впливом З-АБ показало збільшення середнього значення $\beta$-АРМ сер порівняно з контролем $(p<0,05)$ (табл. 1).

Отримані результати вказують на знижену здатність адренорецепторів (АРц) на мембранах еритроцитів зв'язувати блокатори внаслідок ефекту десенсибілізації, що відмічається вже з 1-ї доби захворювання та узгоджується з літературними даними про пошкодження МРК у відповідь на гіпоксію [20].

Для більш повної характеристики показника ß-АРМ сер було проведено вивчення динаміки його змін у хворих на ІГМ залежно від ступеня тяжкості захворювання (табл. 2).

3 результатів, наведених у таблиці 2, стає очевидним, що показники В-АРМ осіб контрольної групи перебували в межах норми (середній груповий показник склав $(15,3 \pm 4,4)$ УО), що відповідає нормальній $\beta$-АРМ (2-20 УО). У хворих із середнім

Таблиця 1. Загальні значення $\beta-A Р M_{\text {сер }}$ у хворих на ІГМ в динаміці лікування

\begin{tabular}{|l|c|c|c|}
\hline \multirow{2}{*}{ Група хворих } & \multicolumn{3}{|c|}{$\beta-$-АРМ $_{\text {сер }}$ (УО) } \\
\cline { 2 - 4 } & 1 1-а доба & 10 -а доба & 21 -ша доба \\
\hline Всі & $36,3 \pm 3,72$ & $25,68 \pm 3,32$ & $23,73 \pm 3,48$ \\
\hline 1 група & $35,88 \pm 2,94$ & $28,67 \pm 3,52$ & $16,61 \pm 2,18$ \\
\hline 2 група & $36,62 \pm 3,24$ & $23,22 \pm 2,63$ \\
\hline Контрольна група & \multicolumn{3}{|c|}{$15,3 \pm 4,4$} \\
\hline
\end{tabular}

Примітки: Всі показники достовірні $(p<0,05)$ відносно контрольної групи; * - p<0,05 до та після лікування всередині групи.

Таблиця 2. Динаміка значень ß-АРМсер у хворих на ІГМ залежно від ступеня тяжкості захворювання, УО

\begin{tabular}{|l|c|c|}
\hline \multirow{3}{*}{1 Група хворих } & Термін дослідження & Ступінь тяжкості ІГМ \\
\hline \multirow{3}{*}{2 група } & 1 -а доба & $30,21 \pm 2,47$ \\
\cline { 2 - 3 } & 10 -а доба & $26,38 \pm 3,22$ \\
\cline { 2 - 3 } & 21 -а доба & $21,55 \pm 2,87$ \\
\hline Контрольна група & 1 -а до6а & $42,43 \pm 3,64$ \\
\cline { 2 - 3 } & 10 -а доба & $37,65 \pm 3,11$ \\
\cline { 2 - 3 } & 21 -а доба & $32,75 \pm 2,72$ \\
\hline
\end{tabular}

Примітка. Всі показники достовірні $(p<0,05)$ відносно контролю. 
Огляди літератури, оригінальні дослідження, погляд на проблему, випадок з практики, короткі повідомлення ступенем тяжкості ІГМ показник перевищував нормальні значення в 1,97 раза, що характерно для середнього ступеня В-АРМ (21-40 УО), тобто вказує на знижену здатність АРц мембран еритроцитів зв'язувати блокатор унаслідок ефекту десенсибілізації. Аналогічна ситуація спостерігалася 3 еритроцитами хворих із тяжким перебігом захворювання, де показник $\beta$-АРМ перевищував нормальні значення в 2,8 раза і характеризувався низьким ступенем $\beta$-АРМ (>41 УО).

Наступним етапом дослідження було вивчення динаміки змін значень КДП суспензії еритроцитів під впливом біологічно активних речовин методом КВЧ діелектрометрії. У таблиці 3 представлені відносні значення реальної частини ді-

електричної проникності, що являє собою різницю між виміряною КДП до та після впливу адреналіном.

Як видно даних, наведених у таблиці 3, відносні значення $\Delta \varepsilon^{\prime}$ були чітко диференційованими за групами. У контрольній групі спостерігалося істотне зменшення $\Delta \varepsilon^{\prime}$ після впливу розчином адреналіну. У хворих на ІГМ реакція на адреналін була практично відсутня, що можна пов'язати зі зниженням чутливості $\beta$-АРц еритроцитів до стимулюючих речовин внаслідок їх десенсибілізації. Однак за величиною змін показника $\Delta \varepsilon^{\prime}$ у групі хворих із середнім ступенем тяжкості можна стверджувати, що еритроцити їх були більш реактивними, ніж у групі хворих із більш тяжким варіантом ІГМ.

Таблиця 3. Динаміка значень $\Delta \varepsilon^{\prime}$ суспензій еритроцитів після впливу адреналіном у хворих на ІГМ залежно від ступеня тяжкості захворювання

\begin{tabular}{|c|c|c|}
\hline \multirow{3}{*}{ Група хворих } & Термін дослідження & Значення $\Delta \varepsilon^{\prime} \pm$ s \\
\hline \multirow{3}{*}{1 група } & 1 -а доба & $0,21 \pm 0,08$ \\
\cline { 2 - 3 } & 10 -а доба & $0,33 \pm 0,04$ \\
\cline { 2 - 3 } 2 група & 21 -а доба & $0,35 \pm 0,1$ \\
\cline { 2 - 3 } & 1 -а доба & $-0,48 \pm 0,18$ \\
\hline \multirow{2}{*}{ Контрольна група } & 10 -а доба & $-0,33 \pm 0,09$ \\
\cline { 2 - 3 } & 21 -а доба & $-0,31 \pm 0,04$ \\
\hline
\end{tabular}

Примітка. Всі показники достовірні відносно контролю $(p<0,05)$.

Подібний ефект спостерігали також при порівнянні динаміки змін значень $\Delta \varepsilon^{\prime}$ суспензій ери-

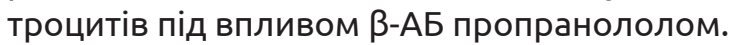

У динаміці захворювання спостерігали тенденцію до збільшення абсолютних значень КДП на фоні призначеного лікування, що свідчить про зміни рівнів гідратації еритроцитів за рахунок зменшення товщини примембранного шару до $20 \%$. Це впливає на швидкість обмінних процесів у системі «клітина - міжклітинне середовище», тим самим змінюючи режим функціонування клітини.

Отже, виявляючи збільшення фракції вільної води в клітинах можна зробити висновок про позитивний ефект лікування, що підтверджується фізико-біологічними методами на рівні МРК.

Отримані результати вказують на перспективність методів ОРЕ та КВЧ діелектрометрії для моніторингу функціонального стану хворих із ІГМ у динаміці лікування.

При комплексному аналізі отриманих результатів виділено ключові патогенетичні механізми розвитку та прогресування гострої церебральної ішемії з трансформацією в мозковий інфаркт і, виходячи з цього, запропоновано діагностичні критерії тяжкості захворювання, що прямо впливають на наслідок.
У дебюті ІГМ відбувається достовірне підвищення значень $\beta$-АРМ в 2,4 раза, порівняно з контролем. Максимальні рівні $\beta$-APM $((42,43 \pm 3,64)$ УО) відмічаються у хворих із початково тяжким ступенем захворювання (неврологічний дефіцит за шкалою NIHSS 21 бал й вище), що вказує на значне напруження роботи симпатоадреналової системи у цих хворих.

Виявлений прямий кореляційний зв'язок між сумарним клінічним балом та рівнем $\beta$-АРМ у хворих у найгострішому періоді ІГМ $(r=+0,93 ; p<0,05)$ без зміни напрямку в динаміці захворювання свідчить про більш потужне ураження МРК у тяжких хворих.

Про вплив адренорецепторної дисфункції на ступінь тяжкості хворих у гострому періоді ІГМ свідчить наявність зворотного кореляційного зв'язку між КДП та сумарним клінічним балом ( $r=-0,83$; p<0,05). Зворотні достовірні кореляційні зв'язки між значеннями КДП та $\beta$-АРМ під час госпіталізації хворих (r=-0,76; $p<0,05)$ і в динаміці захворювання $(r=-0,73 ; p<0,05)$ свідчать про значне ураження МРК клітин на фоні активації симпатоадреналової системи.

Про знижену здатність АРц на мембранах еритроцитів зв'язувати блокатори внаслідок 
Огляди літератури, оригінальні дослідження, погляд на проблему, випадок з практики, короткі повідомлення ефекту десенсибілізації за рахунок пошкодження МРК свідчить встановлений прямий достовірний зв'язок між площею інфарктної зони та значеннями $\beta$-АРМ $(r=+0,88 ; p<0,05)$.

Виявлений зворотний кореляційний зв'язок між значеннями КДП та об'ємом ураженої зони ( $r=-0,87 ; p<0,05)$ може вказувати на наявність потужної дисфункції адренорецепторної системи, що залежить від масивності ураження тканини мозку.

Висновки. У ході проведеного дослідження було вперше розроблено інформативний комплексний підхід для оцінки ß-АРМ еритроцитів пе-

\section{ЛІТЕРАТУРА}

1. Heart disease and stroke Statistics-2019 update a report from the American Heart Association / E. J. Benjamin, P. Muntner, A. Alonso [et al.] // Circ. - 2019. Vol. 39 (10). - P. E526-E528.

2. Feigin V. L. Global burden of stroke / V. L. Feigin, B. Norrving, G. A. Mensah // Circ. Res. - 2017. - Vol. 120 (3). P. 439-448.

3. Boehme A. K. Stroke risk factors, genetics, and prevention / A. K Boehme, C.Esenwa, M. S. V Elkind // Circ. Res. - 2017. - Vol. 120 (3). - P. 472-495.

4. Ranta A. Health economics of cerebrovascular disease. Can we do better? / A. Ranta, J. H. Lichtman // Neurol. - 2015. - Vol. 84 (22). - P. 2204-2205.

5. Global stroke statistics / A. G. Thrift, T. Thayabaranathan, G. Howard [et al.] // Int. J. Stroke. -2017. - Vol. 12 (1). P. 13-32.

6. Guzik A. Stroke epidemiology and risk factor management / A. Guzik, C. Bushnell // Continuum (Minneap Minn). - 2017. - Vol. 23 (1). - P. 15-39.

7. Міщенко Т. С. Епідеміологія цереброваскулярних захворювань і організація допомоги хворим з мозковим інсультом в Україні / Т. С Міщенко // Укр. вісн. психоневрол. - 2017. - Т. 25. - Вип. 1 (90). - С. 22-24.

8. Гандзюк В. А. Динаміка захворюваності та поширеності хвороб системи кровообігу населення України на сучасному етапі: національний та регіональний аспекти / В. А. Гандзюк // Вісн. соц. гігієни та організації охорони здоров'я України. - 2014. - Т. 2 (60). - С. 74-78.

9. Віничук С. М. Епідеміологія транзиторних ішемічних атак у структурі гострих порушень мозкового кровообігу в Україні та інших країнах / С. М. Віничук, О. Є. Фартушна // Міжнар. неврол. журн. - 2017. - Т. 5. C. $105-111$.

10. Фартушна О. Є. Виявлення та усунення васкулярних чинників ризику - важливий напрямок первинної профілактики транзиторних ішемічних атак та/чи інсульту / О. Є. Фартушна, С. М. Віничук // Укр. мед. часопис. -2015 . - Т. 1, № 105. - С. 23-27.

11. Пат. 1811376 A 3 SU A 61 B 5/02. Спосо6 прогнозирования исходов острого инфаркта миокарда / Швед Н. И., Бакалюк О. И., Жулкевич И. В. ; заявитель и патентообладатель Тернопольский гос. мед. ин-т. - No 4899556/14, заявл. 03.01.1991, опубл. 23.04.1993. Бюл. № 15.

риферійної крові у хворих на ІГМ, який заснований на аналізі змін їх діелектричних характеристик і ступеня ОРЕ під дією адренергічних лікарських засобів. Застосування цього підходу показало, що відхилення КДП еритроцитів, що були індуковані адренергічними речовинами, $\epsilon$ проявом специфічної реакції клітин і залежать від функціонального стану симпатоадреналової системи.

Перспективи подальших досліджень. Розроблений метод для оцінки $\beta$-АРМ еритроцитів $\epsilon$ перспективним для створення медико-діагностичного тесту гострої цереброваскулярної патології на ранніх стадіях її розвитку.

12. Bivard A. Tissue is more important than time: insights into acute ischemic stroke from modern brain imaging / A. Bivard, M. Parsons // Curr. Opin. Neurol. - 2018. Vol. 31 (1). - P. 23-27.

13. Results of membrane-activated chelator stroke intervention randomized trial of DP-b99 in acute ischemic stroke / K. R. Lees, N. Bornstein, H. C. Diener [et al.] // Stroke. - 2013. - Vol. 44 (3). - P. 580-584.

14. Allen C. L. Oxidative stress and its role in the pathogenesis of ischaemic stroke / C. L. Allen, U. Bayraktutan // Int. J. Stroke. - 2009. - Vol. 4 (6). - P. 461-470.

15. Christensen $\mathrm{H}$. Proinflammatory cytokines and glutamate in acute stroke / H. Christensen // Stroke. 2001. - Vol. 32 (5). - P. 1234-1234.

16. Identifying autonomic nervous system dysfunction in acute cerebrovascular attack by assessments of heart rate variability and catecholamine levels / E. Akil, Y. Tamam, M. A. Akil [et al.] // J. Neurosci. Rural Pract. 2015. - Vol. 6 (2). - P. 145-153.

17. Insular stroke is associated with acute sympathetic hyperactivation and immunodepression / U. Walter, A. Kolbaske, R. Patejdl [et al.] // Eur. J. Neurol. - 2013. Vol. 20 (1). - P. 153-159.

18. Методологічні підходи до вивчення якості життя в гематологічних дослідженнях / І. В. Жулкевич, С. І. Сміян, М. Є. Гаврилюк [та ін.] // Віс. наук. досл. 2000. - № 3. - С. 16-23.

19. Diagnostic potential of microwave techniques in neurology: new insight into beta-adrenergic activity testing / K. Arkhypova, F. Volokh, A. Nosatov [et al.] // Eur. J. Neurol. - 2015. - Vol. 22. - P. 591-591.

20. Effect of millimetre waves on phosphatidylcholine membrane models: a non-thermal mechanism of interaction / A. Beneduci, K. Cosentino, S. Romeo [et al.] // Soft Matter. - 2014. - Vol. 10 (30). - P. 5559-5567.

21. Johnson J. A. Beta-adrenergic receptor polymorphisms: Cardiovascular disease associations and pharmacogenetics / J. A. Johnson, S. G. Terra // Pharm. Res. - 2002. Vol. 19 (12). - P. 1779-1787.

22. Hausdorff W. P. Turning off the signal desensitization of beta-adrenergic receptor function / W. P. Hausdorff, M. G. Caron, R. J. Lefkowitz // FASEB J. - 1990. Vol. 4 (11). - P. 2881-2889. 
Огляди літератури, оригінальні дослідження, погляд на проблему, випадок з практики, короткі повідомлення REFERENCES

1. Benjamin, E.J., Muntner, P., Alonso, A., Bittencourt, M.S., \& Callaway, C.W. (2019). Heart disease and stroke Statistics-2019 update a report from the American Heart Association. Circ., 10, E526-E528.

2. Feigin, V.L., Norrving, B., \& Mensah, G.A. (2017). Global burden of stroke. Circ. Res., 3, 439-448.

3. Boehm, A.K., Esenwa, C., \& Elkind, M.S.V. (2017). Stroke risk factors, genetics, and prevention. Circ. Res., 3, 472-495.

4. Ranta, A., \& Lichtman, J.H. (2015). Health economics of cerebrovascular disease. Can we do better? Neurol., 22, 2204-2205.

5. Thrift, A.G., Thayabaranathan, T., Howard, G., Howard, V.J., Rothwell, P.M., ..., \& Cadilhac, D.A. (2017). Global stroke statistics. Int. J. Stroke, 1, 13-32.

6. Guzik, A., \& Bushnell, C. (2017). Stroke epidemiology and risk factor management. Continuum (Minneap Minn), 1 , 15-39.

7. Mishchenko, T.S. (2017). Epidemiolohiia tserebrovaskuliarnykh zakhvoriuvan i orhanizatsiia dopomohy khvorym z mozkovym insultom v Ukraini [Epidemiology of cerebrovascular diseases and organization of medical care for patients with stroke in Ukraine]. Ukr. Visn. Psykhonevrol. Ukrainian Bull. Psychoneurol., 25, 1 (90), 22-24 [in Ukrainian].

8. Handziuk, V.A. (2014). Dynamika zakhvoriuvanosti ta poshyrenosti khvorob systemy krovoobihu naselennia Ukrainy na suchasnomu etapi: natsionalnyi ta rehionalnyi aspekty [Dynamics of morbidity and prevalence of cardiovascular diseases among ukrainian population at the present stage: national and regional aspects]. Visn. sots. hihiieny ta orhanizatsii okhorony zdorovia Ukrainy-Bulletin of Soc. Hygiene and Health Protection Organization of Ukraine, 2, 74-78. Retrieved from: https://doi.org/10.11603/16812786.2014.2.3376 [in Ukrainian].

9. Vinychuk, S.M., \& Fartushna, O.Ye. (2017). Epidemiolohiia tranzytornykh ishemichnykh atak u strukturi hostrykh porushen mozkovoho krovoobihu v Ukraini ta inshykh krainakh [Epidemiology of transient ischemic attacks in the structure of acute cerebrovascular disorders in Ukraine and in other countries]. Mizhnar. Nevrol. zhurn. Int. Neurol. J., 5, 105-111 [in Ukrainian].

10. Fartushna, O.Ye., \& Vinychuk, S.M. (2015). Vyiavlennia ta usunennia vaskuliarnykh chynnykiv ryzyku - vazhlyvyi napriamok pervynnoi profilaktyky tranzytornykh ishemichnykh atak ta/chy insultu [Detection and removal of vascular risk factors as important area of primary prevention of transient ischemic attack]. Ukrainskyi medychnyi chasopys Ukrainian Medical Journal, 1 (105), 23-27 [in Ukrainian].

11. Shved, N.I., Bakaliuk, O.I., \& Zhulkevich, I.V. (1993). Pat. SU 1811376 A 3 A 61 V 5/02. Sposob prognozirovaniya iskhodov ostrogo infarkta miokarda [Pat. SU 1811376 A 3 A 61 B 5/02. A method for predicting the outcomes of acute myocardial infarction]; zayavitel i patentoobladatel Ternopolskiy gosudarstvennyy meditsinskiy institut. No 4899556/14, zayavl. 03.01.1991, opubl. 23.04.1993. Byul. No 15 [in Russian].

12. Bivard, A., \& Parsons, M. (2018). Tissue is more important than time: insights into acute ischemic stroke from modern brain imaging. Curr. Opin. Neurol., 1, 23-27.

13. Lees, K.R., Bornstein, N., Diener, H.C., Gorelick, P.B., Rosenberg, G., Shuaib, A., \& Investigators, M. (2013). Results of membrane-activated chelator stroke intervention randomized trial of DP-b99 in acute ischemic stroke. Stroke, 3, 580-584.

14. Allen, C.L., \& Bayraktutan, U. (2009). Oxidative stress and its role in the pathogenesis of ischaemic stroke. Int. J. Stroke, 6, 461-470.

15. Christensen, H. (2001). Proinflammatory cytokines and glutamate in acute stroke. Stroke, 5, 1234-1234.

16. Akil, E., Tamam, Y., Akil, M.A., Kaplan, I., Bilik, M.Z., Acar, A., \& Tamam, B. (2015). Identifying autonomic nervous system dysfunction in acute cerebrovascular attack by assessments of heart rate variability and catecholamine levels. J. Neurosci. Rural Pract., 2, 145.

17. Walter, U., Kolbaske, S., Patejdl, R., Steinhagen, V., Abu-Mugheisib, M., Grossmann, A., ..., \& Benecke, R. (2013). Insular stroke is associated with acute sympathetic hyperactivation and immunodepression. Eur. J. Neurol., 1, 153-159.

18. Zhulkevich, I.V., Smiyan, S.I., Havrylyuk, M.E., Kmita, G.G., Kramar, L.T., \& Korchinska, R.M. (2000). Metodolohichni pidkhody do vyvchennia yakosti zhyttia v hematolohichnykh doslidzhenniakh [Methodological approaches to the study of quality of life in hematological research]. Visn. Nauk. Dosl. - Bull. of Sci. Res., 3, 16-23 [in Ukrainian].

19. Arkhypova, K., Volokh, F., Nosatov, A., \& Malakhov, V. (2015). Diagnostic potential of microwave techniques in neurology: new insight into beta-adrenergic activity testing. Eur. J. Neurol., 22, 591-591.

20. Beneduci, A., Cosentino, K., Romeo, S., Massa, R., \& Chidichimo, G. (2014). Effect of millimetre waves on phosphatidylcholine membrane models: a non-thermal mechanism of interaction. Soft Matter, 30, 5559-5567.

21. Johnson, J.A., \& Terra, S.G. (2002). Beta-adrenergic receptor polymorphisms: Cardiovascular disease associations and pharmacogenetics. Pharm. Res., 12, 1779-1787.

22. Hausdorff, W.P., Caron, M.G., \& Lefkowitz, R.J. (1990). Turning off the signal desensitization of betaadrenergic receptor funktion. FASEB J., 11, 2881-2889. 


\author{
Медицинский институт Сумского государственного университета
}

PEЗЮМЕ. В статье представлены результаты исследования функционального состояния показателей симпатоадреналовой системы больных с инфарктом головного мозга (ИГМ). Разработаны новые лечебно-прогностические критерии заболевания на основе выявленных изменений.

Цель - усовершенствование диагностического алгоритма исследования больных в остром периоде ИГМ с учётом особенностей изменений $\beta$-адренергической активности цитоплазматических мембран (АРМ) эритроцитов и установление новых прогностических факторов исходов заболевания.

Материал и методы. Основой работы были материалы комплексного обследования 350 больных с первым в жизни ИГМ на 1-й, 10-й и 21-й дни заболевания. Тяжесть состояния и степень неврологического дефицита объективизировали с помощью шкалы инсульта Национального института здоровья США (NIHSS) с оценкой в баллах в первые часы заболевания, в динамике лечения на 10-е и 21-е сутки. Было выделено 2 клинические группы: 1-я (n=183) больные в состоянии средней степени тяжести (средний балл по шкале NIHSS 11,74 $\pm 0,33)$ и 2-я (n=167) - больные в тяжёлом состоянии (средний балл по шкале NIHSS 24,06士0,29). Измерения комплексной диэлектрической проницаемости (КДП) проводили методом КВЧ диэлектрометрии. Изменения осмотической резистентности эритроцитов (ОРЭ) под действием $\beta$-адреноблокаторов (В-АБ) определяли методом фотоэлектронной колориметрии.

Результаты. В дебюте ИГМ происходит достоверное повышение уровня $\beta$-АРМ в 2,4 раза по сравнению с контролем. Максимальные уровни $\beta$-АРМ $((42,43 \pm 3,64)$ УЕ) отмечаются у больных с исходно тяжелой степенью заболевания, что указывает на значительное напряжение работы симпатоадреналовой системы у данных больных.

В ходе проведенного исследования был впервые разработан информативный комплексный подход для оценки ß-АРМ эритроцитов периферической крови у больных с ИГМ, который основан на анализе изменений их диэлектрических характеристик и степени ОРЭ под действием адренергических лекарственных средств.

Выводы. Применение данного подхода показало, что отклонения КДП эритроцитов, которые были индуцированы адренергическими веществами, являются проявлением специфической реакции клеток и зависят от функционального состояния симпатоадреналовой системы.

КЛЮЧЕВЫЕ СЛОВА: симпатоадреналовая система; рецептор; диагностика; мембрана; реактивность.

\title{
CURRENT POSSIBILITIES FOR IMPROVING THE DIAGNOSTIC ALGORITHM AND OUTPUT FORECASTING OF ISCHEMIC STROKE
}

@V. S. Lychko

\section{Medical Institute of Sumy State University}

SUMMARY. The article presents the results of a study of the functional state of the sympathoadrenal system in patients with ischemic stroke (IS). New diagnostic and prognostic criteria of the disease based on the identified changes have been developed.

The aim - to improve the diagnostic algorithm for the diagnosis of patients in the acute period of IS taking the peculiarities of changes in $\beta$-adrenergic activity of cytoplasmic membranes (ARM) of erythrocytes and establishing new prognostic factors.

Material and Methods. The work was based on the materials of a comprehensive examination of 350 patients with the first in the life of IS on the 1st, 10th and 21st day of the disease. The severity of the condition and the degree of neurological deficit were objectified using the stroke scale of the National Institutes of Health (NIHSS). There were 2 clinical groups: group 1 ( $n=183)$ - patients in a state of moderate severity (mean score on the NIHSS scale $11.74 \pm 0.33$ ); group 2 ( $n=167)$ - patients with severe IS (average score on the NIHSS scale 24.06 \pm 0.29 ). Measurements of complex dielectric constant (CDC) were performed by EHF dielectrometry. Changes in the osmotic resistance of erythrocytes (ORE) under the action of $\beta$-blocker $(\beta-A B)$ were determined by photoelectron colorimetry.

Results. In the debut of IS there is a significant increase in the values of $\beta$-ARM in 2.4 times compared with the control. Maximum levels of $\beta$-ARM $(42.43 \pm 3.64 \mathrm{IU})$ were observed in patients with initially severe disease, which indicates significant stress on the sympathoadrenal system in these patients.

The study was the first to develop an informative, comprehensive approach to the evaluation of peripheral blood erythrocytes in patients with IS, which is based on the analysis of changes in their dielectric characteristics and the degree of ORE under the action of adrenergic drugs.

Conclusions. The application of this approach showed that the deviation of CDC of erythrocytes that were induced by adrenergic substances is a manifestation of a specific response of cells and depends on the functional state of the sympathoadrenal system.

KEY WORDS: sympathoadrenal system; receptor; diagnostics; membrane; reactivity.

Отримано 22.08.2020 